\title{
SIFAT KEILMUAN ANTROPOLOGI HUKUM
}

\author{
Nama Mahasiswa:DANDY DAMARA \\ Email: dandioppo1@gmail.com \\ No BP:2010003600066 \\ UNIVERSITAS EKASAKTI
}

\section{A. PENDAHULUAN}

ANTROPOLOGI HUKUM Masalah Hukum, tidaklah hanya pada masalah Hukum yang Normatif (dalam Perundangan) dan masalah hukum yang merupakan Pola perilaku yg sering terjadi ( Hukum Adat ). Tetapi juga masalah Budaya terhadap suatu masalah Hukum, dikarenakan adanya Faktor Budaya yg mempengaruhinya. Faktor-faktor Budaya yg melatarbelakangi Masalah Hukum ; misalnya, Cara-cara menyelesaikan Masalah Perselisihan dikalangan Orang Batak, tidak sama dengan orang Minang, Jawa, Bali, Maluku dan lainya Caracara tersebut menjai Objek perhatian Antrop Hukum

Sifat Keilmuan 1. Antropologi Hukum tidak membatasi pandangan pada kebudayaan tertentu ( studi perbandingan ) 2. Antroplogi Hukum, mempelajari masyarakat sebagai suatu keseluruhan yg utuh, dimana bagian2nya saling bertautan 3. Antropologi Hukum Modern tidak memusatkan perhatian hanya pd kekuatan sosial dan hal superorganis 4. Antropologi Hukum memandang masyarkat secara Dinamis, sehingga peranan sosial dan Hukum tidak terbatas memper tahankan Status quo 5. Antropologi Hukum termasuk ilmu Hukum yg empiris

\section{B. PEMBAHASAN}

\section{Sifat Keilmuan Antropologi Hukum}

1. Antropologi Hukum tidak membatasi pandangan pada kebudayaan tertentu (studi perbandingan).

2. Antroplogi Hukum, mempelajari masyarakat sebagai suatu keseluruhan yang utuh, dimana bagian-bagiannya saling bertautan.

3. Antropologi Hukum Modern tidak memusatkan perhatian hanya pada kekuatan sosial dan hal superorganis.

4. Antropologi Hukum memandang masyarakat secara Dinamis, sehingga peranan sosial dan Hukum tidak terbatas mempertahankan status quo.

5. Antropologi Hukum termasuk ilmu Hukum yang empiris.

\section{PENUTUP}

Kajian Antropologi Hukum adalah menggali norma dan nilai-nilai dalam masyarakat. Arena Antropologi Hukum mempelajari manusia dan budaya hukum, karenanya kaidah sosial yang tidak bersifat hukum bukanlah sasaran pokok penelitian Antropologi Hukum. Norma / kaidah menurut Antropologi Hukum pola ulangan perilaku dalam masyarakat. 
Norma / Kaidah adalah nilai dasar yang ada dalam masyarakat yang dapat mengukur perilaku manusia agar dapat menilai mana perbuatan benar dan mana yang tidak benar.

Norma memiliki aspek hukum ketika aparat menjatuhkan sanksi karena ada perbuatan yang menyimpang atau melanggar hukum.

Sanksi bersifat positif seperti dengan membayar denda atau kerja sosial, dan sanksi bersifat negatif seperti hukuman badan atau dikucilkan..

Hukum muncul dari peradaban manusia, dimana ada 2 orang atau lebih di situ ada hukum.

\section{DAFTAR PUSTAKA}

Gokma Toni Parlindungan S, Asas Nebis In Idem Dalam Putusan Hakim Dalam Perkara Poligami Di Pengadilan Negeri Pasaman Sebagai Ceriminan Ius Constitutum, Volume 2, Nomor 1, 2020.

Gokma Toni Parlindungan S, Pengisian Jabatan Perangkat Nagari Pemekaran Di Pasaman Barat Dalam Rangka Pelaksanaan Otonomi Daerah, Ensiklopedia Of Journal, Vol 1 No 2 Edisi 2 Januari 2019,

Harniwati, Peralihan Hak Ulayat Menurut Undang-Undang Nomor 18 Tahun 2004, Volume 1, Nomor 3, 2019.

Jasmir, Pengembalian Status Hukum Tanah Ulayat Atas Hak Guna Usaha, Soumatera Law Review, Volume 1, Nomor 1, 2018.

Jumrawarsi Jumrawarsi, Neviyarni Suhaili, Peran Seorang Guru Dalam Menciptakan Lingkungan Belajar Yang Kondusif, Ensikopedia Education Review, Vol 2, No 3 (2020): Volume 2 No.3 Desember 2020

Mia Siratni, Proses Perkawinan Menurut Hukum Adatdi Kepulauan Mentawai Di Sebelum Dan Sesudah Berlakunya Undang-Undang Nomor 1 Tahun 1974 Tentang Perkawinan, Ensiklopedia Of Journal, Vol 1 No 2 Edisi 2 Januari 2019,

Remincel, Dimensi Hukum Pelanggaran Kecelakaan Lalu Dan Angkutan Jalan Lintas Di Indonesia, Ensiklopedia Social Review, Volume 1, Nomor 2, 2019.

R Amin, B Nurdin, Konflik Perwakafan Tanah Muhammadiyah di Nagari Singkarak Kabupaten Solok Indonesia 2015-2019, Soumatera Law Review, Volume 3, Nomor 1, 2020. 